\title{
Komunitas ikan pada terumbu buatan untuk mendukung daerah penangkapan ikan alternatif di selat lembeh Kota Bitung Sulawesi utara
}

Fish communities on artificial reefs to support an alternative fishing ground in Lembeh Strait, Bitung of North Sulawesi

\author{
JUNIANTI J. SOLEMAN*, EMIL REPPIE dan JOHNNY BUDIMAN \\ Program Studi Pemanfaatan Sumberdaya Perikanan, Fakultas Perikanan dan Ilmu Kelautan, \\ Universitas Sam Ratulangi, Manado 95115
}

\begin{abstract}
Artificial reefs are one of the many alternatives that could be used to reduce fishing pressure and natural reef destruction; through the creation of new productive fishing ground. But this kind of scientific information, particularly on reef fish, not widely available. Therefore, the purpose of this research is to study the fish communities on artificial reefs, identify environmental factors that influence fish communities, and assess whether artificial reefs have been built could support an alternative fishing ground. This research was conducted in the Lembeh Strait Bitung City; based on the descriptive method. Nine units of artificial reefs constructed in the form of a hollow block and arranged to resemble a pyramid on the seabed. The structure of fish communities on the artificial reef was observed by using a technique of underwater visual census (UVC) by two SCUBA divers every week for a month. The total number of fish associated with artificial reefs for 4 times observation was 382 individuals; consisting of 14 families, 18 genera and 24 species. Abundance of species assessed by the diversity index (2.57), richness index (3.87) and the evenness index (0.544), classified as moderate criteria. Target fish were observed in association with the new habitat as much as $88 \%$; this shows that artificial reefs have been built could support alternative fishing ground in deeper waters.
\end{abstract}

Keywords: artificial reefs, coral fishes, target species, fishing ground alternative.

\begin{abstract}
ABSTRAK
Terumbu buatan merupakan salah satu dari sekian banyak alternatif yang dapat digunakan untuk mengurangi tekanan penangkapan ikan dan perusakan terumbu karang alami; melalui penciptaan daerah penangkapan ikan baru yang produktif. Namun informasi ilmiah seperti ini, khususnya pada ikan-ikan karang, belum banyak tersedia. Oleh karena itu, tujuan penelitian ini mempelajari komunitas ikan pada terumbu buatan, mengidentifikasi faktor-faktor lingkungan yang berpengaruh, dan menilai apakah terumbu buatan yang telah dibangun dapat mendukung suatu daerah penangkapan ikan alternatif. Penelitian ini dilakukan di Selat Lembeh Kota Bitung; yang didasarkan pada metode deskriptif. Sembilan unit terumbu buatan dikonstruksi dalam bentuk balok berlubang dan disusun menyerupai piramid di dasar laut. Struktur komunitas ikan pada terumbu buatan diamati dengan menggunakan teknik underwater visual census (UVC) oleh dua orang SCUBA divers setiap minggu selama sebulan. Jumlah total ikan yang berasosiasi dengan terumbu buatan selama 4 kali pengamatan adalah 382 individu; terdiri dari14 famili, 18 genus dan 24 spesies. Kelimpahan spesies dinilai dengan indeks keragaman $(2,57)$, indeks kekayaan $(3,87)$ dan indeks keseimbangan $(0,544)$, tergolong kriteria sedang. Ikan target yang teramati berasosiasi dengan habitat baru sebanyak 88\%; hal ini menunjukkan bahwa terumbu buatan yang telah dibangun dapat mendukung daerah penangkapan ikan alternatif di perairan yang lebih dalam.
\end{abstract}

Kata-kata kunci: Terumbu buatan, ikan karang, spesies target, daerah penangkapan alternatif

\footnotetext{
*Penulis untuk penyuratan; email: junianti_soleman@yahoo.com
} 